\title{
Pengaruh Model Pembelajaran Arias dengan Selingan Ice Breaker terhadap Hasil Belajar IPA
}

\author{
N. Md. P. Satriani ${ }^{*}$, Kt. Pudjawan ${ }^{2}$, I Md. Suarjana ${ }^{3}$
}

1,2,3 Jurusan Pendidikan Guru Sekolah Dasar (PGSD), Universitas Pendidikan Ganesha, Singaraja, Indonesia.

\section{A R T I C L E I N F O}

Article history:

Received 19 May 2018

Received in revised form 6 June 2018

Accepted 10 July 2018

Available online 21 August 2018

Kata Kunci:

ARIAS, ice breaker, IPA

Keywords:

ARIAS learning model, ice breaker, natural science

\begin{abstract}
A B S T R A K
Penelitian ini bertujuan untuk mengetahui perbedaan yang signifikan hasil belajar IPA antara kelompok siswa yang mengikuti pembelajaran menggunakan model pembelajaran ARIAS dengan selingan ice breaker dengan kelompok siswa yang mengikuti pembelajaran konvensional pada siswa kelas V SD Gugus II Kecamatan Sukasada Tahun Pelajaran 2017/2018. Jenis penelitian ini adalah penelitian eksperimen semu menggunakan desain nonequivalent posttest only control group design. Populasi penelitian ini adalah seluruh siswa kelas V SD di Gugus II Kecamatan Sukasada Tahun Pelajaran 2017/2018. Sampel penelitian ini adalah SDN 1 Pegayaman, dengan jumlah 32 orang sebagai kelompok eksperimen dan SDN 3 Gitgit dengan jumlah 30 orang. Pemilihan sampel dilakukan dengan teknik random sampling. Pengumpulan data dalam penelitian ini dilakukan menggunakan metode tes dengan instrument tes objektif. Data yang diperoleh dianalisis menggunakan analisis statistik deskriptif, statistik inferensial (uji-t). Berdasarkan perhitungan rata-rata hasil belajar IPA siswa yang mengikuti model pembelajaran ARIAS dengan
\end{abstract} selingan ice breaker adalah 24,03 lebih baik dari rata-rata hasil belajar IPA siswa yang mengikuti pembelajaran konvensional adalah 14,30. Hal tersebut berarti terdapat perbedaan yang signifikan hasil belajar IPA siswa antara kelompok siswa yang mengikuti pembelajaran menggunakan model pembelajaran ARIAS dengan selingan ice breaker dengan kelompok siswa yang mengikuti pembelajaran konvensional. Hal ini menunjukkan bahwa model pembelajaran ARIAS dengan selingan ice breaker berpengaruh terhadap hasil belajar IPA siswa kelas V SD Gugus II Kecamatan Sukasada Tahun Pelajaran 2017/2018.

\section{A B S T R A C T}

This study is aimed at finding out the significant difference of natural science learning result between group of students who took the ARIAS learning with an ice breaker model and group of students who took conventional learning on the fifth grade students of elementary school in Cluster II Sukasada subdiscrit in academic year of 2017/2018. This was a type of quasi experimental study,using post test only non-equivalent control group design. The population of this study was students of the fifth grade in Cluster II Sukasada subdiscrit in academic year of 2017/2018. The samples of this study were the fifth grade students of SDN 1 Pegayaman with consisted of 32 students as the experiment group and SDN 3 Gitgit with consisted of 30 students as the control group. The sampling technique used in this research was the random sampling technique. The collected data in this research were analyzed by using test method with objective test instrument. The obtained data was then analyzed by using descriptive statistic and inferential (t-test). Based on the mean calculations of natural science learning result of the group of students who took ARIAS learning with an ice breaker that is 24,03 better than who took conventional learning that is 14,30 . That means, there is significant difference on the natural science learning result between group ofstudents who took the ARIAS learning with an ice breaker model and group of the students who took conventional learning. This indicates that ARIAS learning with ice breaker take effect toward natural science learning result of the fifth grade elementary school students in Cluster II Sukasada subdiscrit in academic year of 2017/2018.

Copyright (C) Universitas Pendidikan Ganesha. All rights reserved. 


\section{Pendahuluan}

Pendidikan dalam kehidupan manusia memiliki pengaruh yang sangat penting. Pendidikan merupakan salah satu bentuk upaya untuk meningkatkan kualitas Sumber Daya Manusia (SDM) dalam menjamin keberlangsungan pembangunan suatu bangsa. Dengan melaksanakan pendidikan dapat mengembangkan potensi yang dimiliki individu secara optimal yaitu, pengembangan dalam aspek fisik, intelektual, emosional, sosial dan spiritual sesuai dengan tahap perkembangan dan karakteristik lingkungan yang ada disekitarnya. Terbentuknya suatu lembaga pendidikan merupakan sarana untuk mengembangkan potensi yang dimiliki individu. Lembaga pendidikan salah satunya adalah Sekolah Dasar (SD). Susanto (2013) menyatakan tujuan pedidikan di SD yaitu agar siswa mampu memahami potensi diri yang dimilikinya dan dapat merencanakan serangkaian keputusan masa depannya. Agar siswa dapat memahami potensi yang dimiliki, siswa diajarkan berbagai mata pelajaran. Salah satu mata pelajaran yang diajarkan di SD adalah mata pelajaran IPA.

Mata pelajaran IPA memegang peranan penting dalam kehidupan sehari-hari, sebab IPA melatih siswa berpikir logis, rasional, kritis, kreatif dan berpikir secara ilmiah (Samatowa, 2016). Selain itu, "sains' biasa diterjemahkan dengan ilmu pengetahuan alam yang berasal dari kata natural science. Natural artinya alamiah dan berhubungan dengan alam. Science artinya ilmu pengetahuan" (Bundu, 2006:9). "IPA bukan hanya penguasaan kumpulan pengetahuan yang berupa fakta-fakta, atau prinsipprinsip saja, tetapi juga merupakan suatu proses penemuan" (Trianto, 2007:99). Artinya, IPA merupakan sebuah ilmu yang berhubungan dengan cara mencari tahu tentang alam secara sistematis melalui proses penemuan.

IPA merupakan salah satu mata pelajaran pokok dalam kurikulum pendidikan di Indonesia, termasuk pada tingkat SD. IPA diajarkan di SD, agar mencapai tujuan mata pelajaran IPA.

Sudah seharusnya siswa diberikan kesempatan untuk mengkonstruksi pengetahuannya sendiri, berpikir kritis dan kreatif dalam proses pembelajaran IPA. Dengan demikian, kegiatan pembelajaran IPA dapat memberikan pengalaman yang bermakna bagi siswa, sehingga siswa dapat mendapatkan bekal untuk direalisasikan di kehidupan sehari-hari dan masyarakat.

Berdasarkan temuan (Pramana, 2015) menyatakan selama ini keadaan yang berlangsung bukan seperti yang diharapkan. Dalam kegiatan pembelajaran khususnya di SD, pembelajaran IPA masih diajarkan menggunakan pembelajaran secara konvensional. Yasa (2014) menyatakan pembelajaran konvensional adalah salah satu pembelajaran yang hanya memusatkan pada metode ceramah. Tidak terjadinya pembelajaran dua arah, melainkan pembelajaran terfokus dengan pemberian materi yang diberikan guru. Tujuan pembelajaran IPA untuk meningkatkan hasil belajar siswa secara optimal belum dilaksanakan oleh guru secara sistematis, berpola dan terarah di SD.

Alasan ini diperkuat berdasarkan hasil pengamatan yang dilakukan pada 4 Desember 2017 di Gugus II Kecamatan Sukasada, menunjukkan bahwa permasalahan yang berlangsung yaitu: 1) pembelajaran masih kurang variatif, proses pembelajaran yang dilakukan memiliki kecenderungan pada pembelajaran konvensional. 2) penyampaian materi guru dominan menggunakan metode ceramah dalam pembelajaran IPA. 3) proses belajar mengajar guru hanya mengacu pada buku teks sebagai satu-satunya sumber belajar mengajar. 4) Saat guru memberikan pertanyaan kepada siswa, hanya beberapa siswa yang berusaha untuk menjawab. 5) Siswa mengalami kebosanan dan tidak dapat aktif dalam mengkonstruksi pengetahuannya. 6) Kebosanan siswa ditunjukkan dengan terdapat beberapa siswa yang dalam proses pembelajaran mencorat-coret buku pelajaran, mengobrol dengan teman dan mengganggu temannya. Bahkan terdapat siswa baru beberapa menit guru menjelaskan materi, siswa sudah mengantuk.

Hasil wawancara dengan beberapa siswa kelas V di Gugus II Kecamatan Sukasada pada 4 Desember 2017 menunjukkan beberapa hal yaitu: 1) siswa sering merasa bosan dikarenakan guru hanya menggunakan metode ceramah, 2) siswa sering merasa ngantuk karena pembelajaran yang tidak menarik dan 3) siswa kurang senang dengan pembelajaran IPA. Wawancara tidak hanya dilakukan pada siswa kelas V, namun wawancara juga dilakukan dengan wali kelas V di Gugus II Kecamatan Sukasada dengan hasil wawancara yaitu: 1) pembelajaran IPA di kelas V sering dilakukan dengan menerapkan metode ceramah, 2) guru tidak menggunakan media saat pembelajaran dikarenakan media yang tersedia di sekolah terbatas, 3) guru hanya menggunakan buku teks dikarenakan terbatasnya buku penunjang pembelajaran, dan 4) guru tidak menerapkan model pembelajaran dikarenakan guru mengalami kesulitan dalam menerapkan model pembelajaran yang sesuai dengan materi yang diajarkan. Berdasarkan hasil wawancara yang dilakukan terhadap guru dan siswa di SD Gugus II Kecamatan Sukasada dapat disimpulkan bahwa pembelajaran yang berlangsung, yaitu: 1) pembelajaran IPA didominasi dengan metode ceramah, 2) siswa cepat merasa bosan dengan pembelajaran yang diajarkan guru, 3) kurangnya pemahaman guru tentang model maupun strategi dalam pembelajaran, dan 4) pembelajaran yang diajarkan kurang menarik. 
Pembelajaran yang hanya didominasi oleh guru, berdampak pada siswa yang pintar akan mengurangi kesempatan siswa yang memiliki kemampuan akademik yang tergolong rendah untuk aktif dalam proses pembelajaran, sehingga siswa yang memiliki kemampuan akademik yang tergolong rendah akan semakin pasif dalam mengikuti proses pembelajaran. Hal tersebut berdampak pada hasil belajar siswa yang cenderung rendah Hal ini tentunya membuat tujuan pembelajaran IPA tidak dapat terealisasi pada semua siswa. Dampaknya, pada hasil belajar IPA siswa cenderung rendah. Hasil UAS siswa menunjukkan dari 153 siswa terdapat 99 siswa yang mendapatkan nilai di bawah KKM. Hal tersebut dipengaruhi oleh pembelajaran IPA yang berlangsung di kelas.

Mengacu pada permasalahan tersebut, perlu dilakukan perubahan pembelajaran menjadi lebih bermakna. Dalam hal ini, sangat diperlukan penggunaan suatu model pembelajaran yang inovatif, sehingga siswa dapat mengkonstruksi pengetahuan sendiri. Pembelajaran juga harus memberdayakan siswa semaksimal mungkin agar mereka ikut aktif dalam proses pembelajaran. Peran aktif mereka dalam pembelajaran akan menggiring mereka memahami materi-materi yang diajarkan.

Berkenaan dengan hal tersebut, model pembelajaran Assurance, Relevance, Interest, Assessment and Satisfaction (ARIAS) dipilih karena, merupakan salah satu solusi untuk mengatasi permasalahan yang dialami guru di SD. Model pembelajaran ARIAS merupakan model pembelajaran sederhana, sistematik, bermakna, dan dapat digunakan oleh para guru sebagai dasar untuk melaksanakan kegiatan belajar dengan baik (Siahaan, dkk 2010).

Model pembelajaran ARIAS yang digunakan mengandung lima komponen yang merupakan satu kesatuan dalam pembelajaran yaitu; (1) Assurance, yaitu berhubungan dengan sikap percaya, yakin akan berhasil atau yang berhubungan dengan harapan untuk berhasil (Keller dalam Rahman dan Amri, 2014:3), (2) Relevance, yaitu berhubungan dengan siswa baik berupa pengalamn sekarang atau yang telah dimiliki maupun yang berhubungan dengan kebutuhan karir sekarang atau yang akan dating, (3) Interest berhubungan dengan minat dan perhatian siswa, (4) Assessment yaitu berhubungan dengan evaluasi terhadap diri siswa, (5) Satisfaction yaitu yang berhubungan dengan rasa bangga, puas atas hasil yang dicapai. Pramidana (2013) "Keberhasilan dalam belajar harus adanya minat terhadap hal yang dipelajari (interest), dalam belajar perlu adanya proses evaluasi baik selama proses pembelajaran berlangsung maupun pada akhir pembelajaran (assessment), saat pembelajaran siswa harus memiliki rasa bangga terhadap keberhasilan yang dicapainya, sekalipun keberhasilan itu kecil (satisfaction)". Juniartini (2013) mengatakan bahwa "Model pembelajaran Assurance, Relevance, Interest, Assessment, dan Satisfaction (ARIAS) adalah model pembelajaran yang dapat menanamkan rasa yakin/percaya pada siswa melalui relevansinya dengan kehidupan siswa, memelihara minat/perhatian siswa, pemberian evaluasi dan menumbuhkan rasa bangga pada siswa dengan memberikan penguatan (reinforcement) sehingga memberikan pengalaman yang bermakna bagi siswa". Hindayani (2013) menyatakan model pembelajaran ARIAS terdiri atas lima komponen (assurance, relevance, interest, assessment, dan satisfaction) yang disusun berdasarkan teori belajar. "Dalam model ARIAS dituntut kreativitas guru dalam memilih cara mengajar untuk dapat membantu siswa lebih tertarik terhadap materi pelajaran" (Lastia,2013). Garlina berpendapat bahwa "lima komponen dalam proses pembelajaran yaitu, fase assurance (A), fase relevance (R), fase interest (I), fase assessment, dan fase satisfaction (S) merupakan satu kesatuan yang diperlukan dalam kegiatan pembelajaran. "Model pembelajaran ini menanamkan rasa yakin pada siswa dalam mengemukakan pendapat yang dimiliki, menarik dan memelihara minat siswa, serta menumbuhkan rasa bangga pada siswa" (Apriani, 2013). Kushendrati (2013) mengatakan bahwa model pembelajaran yang berusaha untukmenekankan rasa yakin atau percaya pada siswa, berusaha menarik dan memelihara minat atau perhatian siswa serta diadakan evaluasi dan pada akhirnya ingin menumbuhkan rasa bangga pada siswa dengan memberikan penguatan.

Adapun langkah-langkah model pembelajaran ARIAS (Siahaan, dkk, 2010) sebagai berikut. a. Tahap Assurance: (1) menanamkan pada siswa gambaran diri positif terhadap diri sendiri, (2) membantu siswa menyadari kekuatan dan kelemahan diri (menumbuhkan percaya diri). b. Tahap Relevance: (1) memberikan informasi kompetensi yang akan dicapai, (2) mengemukakan tujuan atau manfaat pelajaran bagi kehidupan dan aktivitas siswa baik di masa sekarang maupun mendatang. c. Tahap Interest: pada tahap ini guru memberikan kesempatan siswa untuk berpartisipasi secara aktif dalam pembelajaran dan mengadakan variasi dalam pembelajaran. d. Tahap Asessment: mengukur pemahaman siswa melalui beberapa pertanyaan tertulis. e. Tahap Satisfaction: guru hanya memberikan pujian kepada siswa yang mendapat nilai tertinggi.

Ice breaker digunakan untuk menunjang model pembelajaran ARIAS. Ice breaker merupakan "sentuhan aktivitas yang dapat digunakan untuk memecahkan kebekuan, kekalutan, kejemuan dan kejenuhan suasana sehingga menjadi cair dan suasana bisa kembali pada keadaan semula (lebih kondusif)" (Fanani, 2010). "Ice breaker dalam pembelajaran dapat diartikan sebagai pemecah situasi kebekuan pikiran atau fisik siswa" (Sunarto, 2012:3). 
Penggunaan ice breaker juga memiliki teknik tersendiri dari pelaksanaannya dalam pembelajaran. Sunarto (2012) mengemukakan teknik penggunaan ice breaker dalam pembelajaran ada empat yaitu: (1) ice breaker secara spontan, (2) ice breaker pada awal kegiatan pembelajaran, pembelajaran, (3) ice breaker pada kegiatan inti pembelajaran, dan (4) ice breaker pada akhir kegiatan pembelajaran. Ice breaker merupakan pendukung utama dalam menciptakan suasana pembelajaran yang efektif.

Implementasi model pembelajaran ARIAS dengan selingan ice breaker, pengajar mampu memotivasi siswa untuk belajar dan pemahaman konsep IPA siswa dapat tersampaikan dengan baik, sehingga peningkatan hasil belajar siswa dapat tercapai.

Adapun tujuan penelitian ini adalah untuk mengetahui perbedaan yang signifikan hasil belajar IPA antara kelompok siswa yang mengikuti pembelajaran menggunakan model pembelajaran ARIAS dengan selingan ice breaker dengan kelompok siswa yang mengikuti pembelajaran konvensional pada siswa kelas V SD Gugus II Kecamatan Sukasada Tahun Pelajaran 2017/2018.

\section{Metode}

Penelitian ini dilakukan di SD Gugus II Kecamatan Sukasada Tahun Pelajaran 2017/2018 pada siswa kelas V SD, semester II dari bulan Maret sampai bulan April 2018.

Jenis penelitian ini adalah penelitian eksperimen semu (quasi eksperimen), mengingat tidak semua variabel atau gejala yang muncul dan kondisi eksperimen dapat diatur dan dikontrol secara ketat (full randomize). Penelitian ini merupakan penelitian dengan rancangan desain nonequivalent post test only control group design.

Prosedur pelaksanaan penelitian ini terdiri dari tahapan-tahapan yaitu: 1) tahap awal: a) merancang perangkat pembelajaran, b) menyusun tes instrumen berupa tes objektif, c) melaksanakan uji instrumen yang dilaksanakan oleh ahli (uji judges), d) melaksanakan uji coba instrumen penelitian yang digunakan dalam penelitian, e) revisi dan perbaikan instrumen. 2) tahap pelaksanaan: a) guru memberikan perlakuan kepada kelompok eksperimen dengan model ARIAS dengan selingan ice breaker dan pada kelompok control diberikan pembelajaran dengan pembelajaran konvensional, b) mengadakan tes akhir (post-test) kepada kedua kelompok. 3) tahap akhir: a) memeriksa hasil tes yang telah dilakukan, b) menganalisis data hasil belajar IPA siswa dan menguji hipotesis dengan uji-t, c) membuat laporan mengenai hasil yang diperoleh dalam penelitian.

Populasi adalah "wilayah generalisasi yang terdiri atas: obyek/subyek yang mempunyai kualitas dan karakteristik tertentu yang diterapkan oleh peneliti untuk dipelajari dan kemudian ditarik kesimpulannya" (Sugiyono, 2017:61). Populasi dalam penelitian ini adalah seluruh siswa kelas V SD Gugus II Kecamatan Sukasada yang terdiri dari 6 SD dengan jumlah siswa 153 orang.

Menurut Sudjana (dalam Agung, 2016:8) menyatakan bahwa sampel merupakan sebagian yang diambil dari populasi. Pemilihan sampel dengan teknik random sampling, yaitu teknik pengambilan sampel dari populasi yang dilakukan secara acak.

Sebelum dilakukan penentuan sampel penelitian, dilakukan uji kesetaraan. Uji kesetaraan dilakukan dengan tujuan untuk mengetahui kesetaraan kemampuan akademik kelompok sampel. Uji kesetaraan dilakukan dengan uji Analisis Varian satu jalur (Anava Satu Jalur) dengan bantuan SPSS 21.0 for windows dengan signifikansi 5\%. Jika angka signifikansi hitung kurang dari 0,05 maka kelas tersebut tidak setara. Sedangkan jika angka signifikansi hitung lebih besar dari 0,05 maka kelas tersebut setara. Berdasarkan uji kesetaraan yang telah dilakukan dengan SPSS 21.0 for windows pada taraf signifikansi 5\% maka didapatkan hasil seperti tabel 01.

Tabel 01. Hasil Uji Kesetaraan Kelas V SD Gugus II Kecamatan Sukasada

\begin{tabular}{llll}
\hline No & Kelas & Sig & Keterangan \\
\cline { 1 - 2 } 1 & SDN 1 Pegayaman & & \\
\cline { 1 - 2 } 2 & SDN 2 Pegayaman Kelas A & & \\
\cline { 1 - 2 } 3 & SDN 2 Pegayaman Kelas B & & Setara \\
\cline { 1 - 2 } 4 & SDN 3 Pegayaman & \\
\cline { 1 - 2 } 5 & SDN 2 Gitgit & \\
\hline 7 & SDN 3 Gitgit & & \\
\hline
\end{tabular}

Berdasarkan uji kesetaraan yang dilakukan ke enam SD yang ada di Gugus II Kecamatan Sukasada memiliki kemampuan yang setara. Dalam pemilihan kelas eksperimen dan kelas sampel dilakukan dengan 
cara random. Berdasarkan hasil undian, diperoleh dua kelas, yaitu kelas V SDN 1 Pegayaman yang berjumlah 32 siswa kelompok eksperimen dan Kelas V SDN 3 Gitgit yang berjumlah 30 siswa sebagai kelompok kontrol.

Penelitian ini terdapat dua variabel yaitu variabel bebas dan variabel terikat. Variabel bebas pada penelitian ini adalah model pembelajaran ARIAS dengan selingan ice breaker. Variabel terikat dalampenelitian ini adalah hasil belajar IPA. Dalam penelitian ini menggunakan metode tes. "Tes adalah instrument alat atau prosedur yang sistematis yang terdiri atas seperangkat pertanyaan atau tugas-tugas untuk mengukur suatu perilaku tertentu pada peserta didik dengan menggunakan bantuan skala numerik atau kategori tertentu" (Koyan, 2012:8). Penelitian ini menggunakan metode tes. Metode tes digunakan untuk mengumpulkan data hasil belajar IPA. Instrumen pengumpulan data pada penelitian ini menggunakan soal objektif yang berjumlah 30 soal. Setiap jawaban benar diberikan skor 1 dan jika jawaban salah diberikan skor 0 .

Instrumen tes hasil belajar akan diujicobakan terlebih dahulu sebelum diberikan pada kelas eksperimen dan kelas kontrol. Hal tersebut dilakukan untuk mengetahui valid atau tidak tes yang akan digunakan, reliabilitas, daya pembeda soal dan tingkat kesukaran soal. Data yang telah terkumpul, kemudian dianalisis dengan menggunakan statistik deskriptif dan inferensial. "Statistik deskriptif yaitu statistik yang digunakan untuk menggambarkan atau menganalisis suatu statistik hasil penelitian tetapi tidak digunakan untuk generalisasi/inferensi" (Koyan, 2012:4). Statistik deskriptif yang digunakan dalam penelitian ini yaitu rata-rata (mean), median, dan modus. Statistik inferensial ini digunakan untuk menguji hipotesis melalui uji-t yang diawali dengan analisis prasyarat yaitu uji normalitas dan uji homogenitas.

Uji hipotesis yang dilakukan pada penelitian ini adalah analisis uji t. Hal tersebut dikarenakan, membandingkan satu variabel bebas dan satu variabel terikat dengan menggunakan dua kelompok sampel (Dantes, 2017). Uji hipotesis yang digunakan yaitu independent sampel t-test (sampel tidak berkorelasi) dengan rumus polled varians. Kriteria pengujian adalah $\mathrm{H}_{0}$ diterima $t_{\text {hitung }}<\mathrm{t}_{\text {tabel }}$ dan $\mathrm{H}_{0}$ ditolak jika $t_{\text {hitung }}>t_{\text {tabel, }}$ pada taraf signifikansi $5 \%$..

\section{Hasil dan Pembahasan}

Data hasil penelitian yang dipaparkan adalah data hasil belajar kelompok eksperimen dan kelompok kontrol. Data hasil belajar yang diperoleh dari kelompok eksperimen dengan kelompok kontrol. Kelompok kontrol mengikuti pembelajaran dengan model pembelajaran ARIAS dengan selingan Ice breaker dan kelompok kontrol mengikuti pembelajaran konvensional. Rangkuman hasil analisis data deskriptif disajikan pada tabel 2.

Tabel 2. Deskripsi Data Hasil Belajar IPA Kelompok Eksperimen dan Kelompok Kontrol

\begin{tabular}{ccc}
\hline Statistik & Kelompok Eksperimen & Kelompok Kontrol \\
\hline Mean & 24,03 & 14,30 \\
Median & 24,80 & 13,85 \\
Modus & 26,21 & 13,49 \\
Standar Deviasi & 3.68 & 4,57 \\
Varian & 13,55 & 20,89 \\
\hline
\end{tabular}

Data hasil belajar IPA kelompok eksperimen dieproleh dengan pemberian post-test terhadap 32 orang siswa dengan skor tertinggi 29 dan skor terendah 13. Berdasarkan perhitungan mean, median, dan modus dan dengan mengamati tabel tersebut di atas, diketahui Mo $>\mathrm{Md}>\mathrm{M}$ pada kelompok eksperimen, gambar tersebut disajikan pada grafik polygon menunjukkan grafik juling negatif, yang artinya bahwa sebagian besar skor siswa yang mengikuti pembelajaran menggunakan model pembelajaran ARIAS dengan selingan ice breaker cenderung tinggi. Berdasarkan pedoman konversi skala lima, maka rata-rata skor $(M)=24,03$, Hasil konversi mean kelompok eksperimen berada pada kelompok sangat tinggi.

Berdasarkan perhitungan hasil konversi mean kelompok eksperimen menyatakan skor mean kelompok eksperimen berada pada kelompok sangat tinggi, hal tersebut mencerminkan bahwa sebagian besar siswa mencapai skor tinggi. Data hasil belajar yang diperoleh melalui pemberian post-test pada kelompok eksperimen dapat disajikan ke dalam bentuk kurva polygon, seperti pada Gambar 1. 


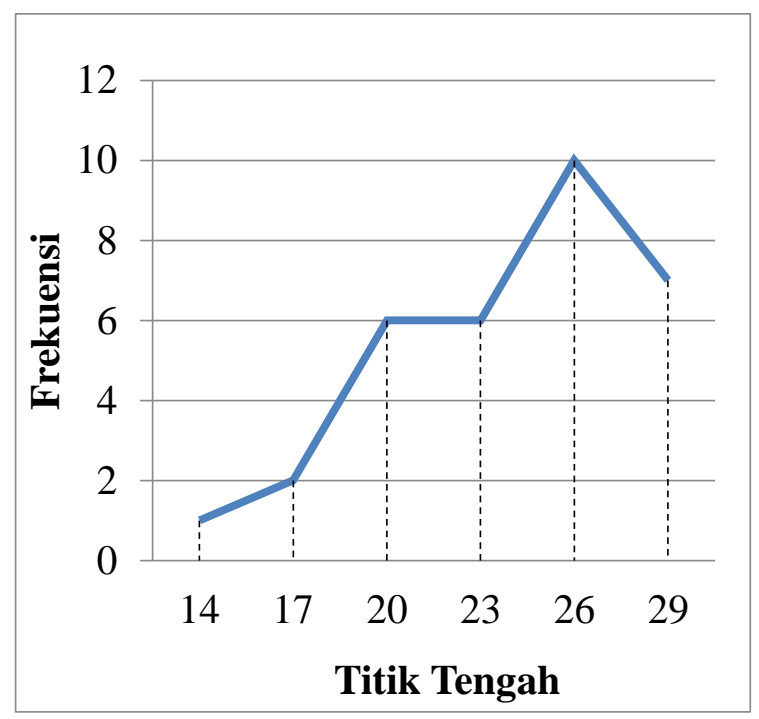

Gambar 1. Polygon Data Hasil Belajar IPA Kelompok Eksperimen

Data pada kelompok kontrol diketahui Mo $<$ Md $<$ M. Setelah digambar dalam kurva polygon menunjukkan kurva juling positif. Hal ini berarti sebagian besar skor pada hasil belajar kelompok kontrol yang mengikuti pembelajaran konvensional cenderung rendah. Data hasil belajar IPA kelompok kontrol dapat disajikan ke dalam kurva polygon, seperti pada gambar 2.

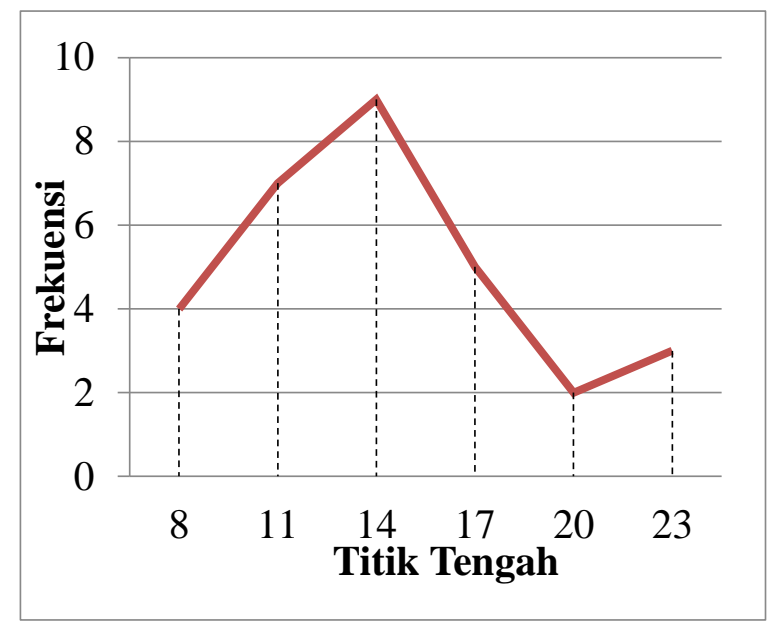

Gambar 2. Polygon Data Hasil Belajar IPA Kelompok Kontrol

Untuk memenuhi uji prasyarat sebelum dianalisis menggunakan uji-t maka terlebih dahulu harus memenuhi beberapa asumsi statistik yaitu Uji Normalitas dan Uji Homogenitas.

Uji normalitas sebaran data dilakukan untuk mengetahui data yang diperoleh berdistribusi normal atau tidak. Jika berdistribusi normal maka uji hipotesis dapat dilakukan. Uji normalitas data dilakukan terhadap hasil belajar IPA kelas eksperimen dan kontrol. Uji normalitas sebaran data dilakukan menggunakan Chi-Kuadrat $\left(\chi^{2}\right)$ pada taraf signifikansi 5\% dengan derajat kebebasan $\mathrm{dk}=\mathrm{k}-$ parameter 1. Adapun kaidah pengujian normalitas sebaran data adalah jika $\chi^{2}$ hitung $<\chi 2$ tabel, maka data berdistribusi normal, sedangkan jika $\chi 2$ hitung $>\chi 2$ tabel, maka data tidak berdistribusi normal. Berdasarkan hasil penghitungan menggunakan rumus Chi-Kuadrat, diperoleh $\chi^{2}$ hitung hasil belajar IPA kelompok eksperimen adalah 5,010 dan $\chi^{2}$ tabel pada taraf signifikansi 5\% dan dk = 3 adalah 7,815. Hal ini berarti, $\chi^{2}$ hitung hasil belajar IPA kelompok eksperimen lebih kecil dari $\chi^{2}$ tabel $\left(\chi^{2}\right.$ hitung $<\chi^{2}$ tabel $)$, sehingga data skor hasil belajar IPA kelompok eksperimen berdistribusi normal.Berdasarkan hasil penghitungan menggunakan rumus Chi-Kuadrat, diperoleh $\chi^{2}$ hitung hasil belajar IPA kelompok kontrol adalah 3,277 dan $\chi^{2}$ tabel pada taraf signifikansi $5 \%$ dan $\mathrm{dk}=3$ adalah 7,815. Hal ini berarti, $\chi^{2}$ hitung hasil belajar IPA 
kelompok kontrol lebih kecil dari $\chi^{2}$ tabel $\left(\chi^{2}\right.$ hitung $<\chi^{2}$ tabel $)$, sehingga data skor hasil belajar IPA kelompok kontrol berdistribusi normal.

Uji homogenitas varians antar kelompok bertujuan untuk memeriksa kesatuan varians antar kelompok perlakuan. Dalam penelitian ini, uji homogenitas dilakukan terhadap varians antar kelompok eksperimen dan kontrol. Uji yang digunakan adalah uji-F dengan kriteria data homogen jika $F_{\text {hitung }}<F_{\text {tabel }}$

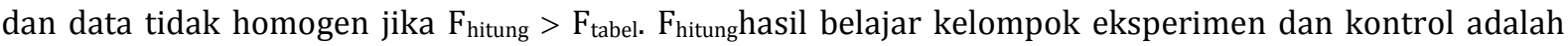
1,82, sedangkan $F_{\text {tabel }}$ pada $\mathrm{db}_{\text {pembilang }}=29$ dan $\mathrm{db}_{\text {penyebut }}=31$ dengan taraf signifikansi $5 \%$ adalah 1,82 sehingga $F_{\text {hitung }}<F_{\text {tabel. }}$ Hal ini berarti varians data hasil belajar IPA kelompok eksperimen dan kontrol adalah homogen.

Pengujian hipotesis dilakukan dengan menggunakan uji-t sampel independent (tidak berkorelasi) dengan rumus polled varians. Kriteria pengujian adalah $\mathrm{H}_{0}$ ditolak jika $t_{\text {hitung }}>\mathrm{t}_{\text {tabel }}$ dan $\mathrm{H}_{1}$ ditolak jika $t_{\text {hitung }}$ $<t_{\text {tabel }}$ dengan $t_{\text {tabel }}$ diperoleh dari tabel distribusi $t$ pada taraf signifikansi $5 \%$ dengan derajat kebebasan $\mathrm{db}$ $=\mathrm{n} 1+\mathrm{n} 2-2$. Rangkuman haisl perhitungan uji-t antar kelompok eksperimen dan kontrol disajikan pada Tabel 3.

Tabel 3. Hasil Perhitungan Uji-t

\begin{tabular}{ccccccc}
\hline Kelompok & $\mathrm{N}$ & $\mathrm{Db}$ & $\bar{X}$ & $\mathrm{~S}$ & $\mathrm{t}_{\text {hitung }}$ & $\mathrm{t}_{\text {tabel }}$ \\
\hline Eksperimen & 32 & 60 & 24,03 & 13,55 & \multirow{2}{*}{9,27} & 2,000 \\
Kontrol & 30 & 60 & 14,30 & 20,89 & & \\
\hline
\end{tabular}

Berdasarkan hasil penghitungan diketahui bahwa nilai $t_{\text {hitung }}=9,27$ dan nilai $t_{\text {tabel }}=2,00$ untuk db= 60 pada taraf signifikansi $5 \%$. Berdasarkan hasil penghitungan tersebut maka $t_{\text {hitung }}>t_{\text {tabel }}(9,27>2,00)$ sehingga $\mathrm{H}_{0}$ ditolak dan $\mathrm{H}_{1}$ diterima. Hal ini berarti bahwa terdapat perbedaan yang signifikan hasil belajar IPA siswa antara kelompok siswa yang mengikuti pembelajaran menggunakan model pembelajaran ARIAS dengan selingan ice breaker dengan kelompok siswa yang mengikuti pembelajaran konvensional. Hal ini menunjukkan bahwa model pembelajaran ARIAS dengan selingan ice breaker berpengaruh terhadap hasil belajar IPA siswa kelas V SD Gugus II Kecamatan Sukasada Tahun Pelajaran $2017 / 2018$.

Berdasarkan deskripsi data hasil penelitian, kelompok siswa yang mengikuti pembelajaran menggunakan model pembelajaran ARIAS dengan selingan ice breaker memiliki skor rata-rata hasil belajar IPA yang lebih tinggi dibandingkan dengan siswa yang mengikuti pembelajaran konvensional.

Berdasarkan analisis sebaran data menggunakan uji-t, diperoleh nilai thitung lebih besar dari pada ttabel ( $t_{\text {hitung }}>t_{\text {tabel }}$ ), sehingga terdapat perbedaan yang signifikan hasil belajar IPA siswa antara kelompok siswa yang mengikuti pembelajaran menggunakan model pembelajaran ARIAS dengan selingan ice breaker dengan kelompok siswa yang mengikuti pembelajaran konvensional. Hal ini dapat dilihat dari skor hasil belajar IPA siswa kelompok eksperimen yang mengikuti pembelajaran menggunakan model pembelajaran ARIAS dengan selingan ice breaker tergolong tinggi. Hal tersebut dipengaruhi oleh beberapa faktor sebagai berikut.

Pertama, pada komponen assurance siswa ditanamkan rasa yakin dan percaya akan kemampuan yang dimilikinya. Pada pembelajaran, apersepsi dapat menjadi salah satu bagian dari tahapan assurance. Siswa kelas eksperimen yang diberikan apersepsi yang sesuai dan menarik terlihat memberikan perhatian terhadap yang dipaparkan oleh guru. Sehingga model pembelajaran ARIAS dengan selingan ice breaker membuat siswa mampu memiliki rasa percaya diri, bersemangat memperhatikan guru dalam proses pembelajaran. Hal tersebut terlihat ketika pembelajaran berlangsung siswa tampak percaya diri saat mengemukakan pendapat dan bertanya.

Kedua, pada komponen relevance pelaksanaan model pembelajaran ARIAS, berkaitan dengan pengalaman siswa atau sesuai dengan kehidupan nyata. Pembelajaran yang berlangsung dikaitkan dengan kehidupan sehari-hari siswa dengan menggunakan contoh-contoh nyata, sehingga siswa bersemangat dan fokus mengikuti pembelajaran yang sedang berlangsung.

Ketiga pada komponen interest, yaitu aspek yang berhubungan dengan minat/perhatian siswa. Pembelajaran model ARIAS dengan selingan ice breaker, siswa dibelajarkan dengan pembelajaran yang menarik seperti menayangkan video dan melakukan percobaan atau eksperimen, sehingga siswa sangat antusias dalam mengikuti pembelajaran. Hal tersebut terlihat ketika mengamati video dan melaksanakan eksperimen, siswa aktif bertanya, berdiskusi dan bekerjasama, sehingga pemahaman siswa terhadap materi yang diajarkan menjadi lebih baik.

Keempat komponen assessment, merupakan suatu bentuk evaluasi selama proses berlangsungnya kegiatan pembelajaran dari awal hingga akhir. Pada pembelajaran yang berlangsung penilaian diberikan 
oleh guru maupun oleh siswa. Penilaian oleh guru diberikan pada saat siswa menjawab soal baik secara lisan maupun tertulis, sedangkan penilaian yang dilakukan oleh siswa diberikan pada saat siswa lain mengungkapkan pendapat atau hasil penemuannya. Dengan adanya kegiatan penilaian yang dilakukan mendorong siswa untuk memperbaiki kemampuannya dengan lebih giat dalam belajar.

Kelima pada komponen satisfaction, yaitu berhubungan dengan rasa bangga atau puas atas hasil yang dicapai. Pada pembelajaran ini, siswa diberikan penguatan berupa pujian, penghargaan bintang dari kertas, tepuk salut dan tepuk good job. Penguatan tersebut diberikan kepada siswa yang telah berpartisipasi aktif dalam proses pembelajaran seperti menjawab pertanyaan yang diajukan guru, kelompok yang aktif dalam pembelajaran serta siswa yang mengemukakan hasil penemuannya.

Keenam pemberian ice breaker, siswa diberikan selingan atau ice breaker pada saat awal pembelajaran dan pada inti pembelajaran. Ice breaker yang diberikan pada awal pembelajaran yaitu berupa ice breaker yang dapat mengembalikan konsentrasi siswa berupa pertanyan-pertanyaan yang mengecoh daya berpikir siswa, sedangkan ice breaker yang diberikan pada saat inti pembelajaran berupa nyanyian maupun permainan-permainan kecil yang dilakukan agar siswa kembali bersemangat untuk mengikuti pembelajaran. Ketika diberikan ice breaker siswa sangat semangat untuk mengikuti pembelajaran sehingga konsentrasi siswa terfokus pada pembelajaran yang sedang berlangsung.

Berdasarkan pemaparan tersebut, dapat disimpulkan model pembelajaran ARIAS dengan selingan ice breaker dapat memudahkan siswa memperoleh dan menguasai materi baru. Siswa tidak mudah jenuh dan konsentrasi siswa tetap terfokus pada pembelajaran. Siswa lebih percaya diri dalam menyampaikan pendapat. Siswa aktif berinteraksi dengan seluruh peserta didik di dalam kelas.

\section{Simpulan dan Saran}

Berdasarkan rumusan masalah simpulan penelitian ini adalah terdapat perbedaan yang signifikan hasil belajar IPA siswa antara kelompok siswa yang mengikuti pembelajaran menggunakan model ARIAS dengan selingan ice breaker dan kelompok siswa yang mengikuti pembelajaran dengan pembelajaran konvensional. Hasil uji-t menunjukkan nilai thitung tabel $(9,27$ ? 2,00) pada taraf signifikansi $5 \%$ dengan derajat kebebasan sebesar 60. Selain itu rata-rata skor hasil belajar IPA siswa yang mengikuti pembelajaran menggunakan model pembelajaran ARIAS dengan selingan ice breaker $(24,03)$ lebih tinggi daripada rata-rata skor siswa yang mengikuti pembelajaran konvensional $(14,30)$. Dengan demikian, model pembelajaran ARIAS dengan selingan ice breaker berpengaruh terhadap hasil belajar IPA siswa kelas V SD Gugus II Kecamatan Sukasada tahun pelajaran 2017/2018.

Saran yang dapat disampaikan berdasarkan penelitian yang telah dilakukan sebagai berikut.(1) Disarankan kepada guru hendaknya mencoba mengembangkan kompetensinya dalam hal penerapan model-model pembelajaran yang inovatif sehingga pembelajaran yang berlangsung menyenangkan dan dapat meningkatkan hasil belajar IPA siswa. 2) Siswa-siswa di sekolah dasar agar lebih aktif mengikuti pembelajaran dan terus mengembangkan dengan membangun sendiri pengetahuannya melalui mencoba dan pengamatan secara langsung. 3) Bagi peneliti yang berminat untuk mengadakan penelitian lebih lanjut tentang model pembelajaran ARIAS dengan selingan ice breaker pada pelajaran IPA maupun yang lainnya yang sesuai. Hasil dari penelitian ini diharapkan dijadikan pedoman dalam penelitian yang akan dilaksanakan.

\section{Daftar Rujukan}

Agung, A.A.G. 2012. Metodologi Penelitian Pendidikan. Singaraja: Undiksha.

Agung, A.A.G. 2016. Statistika Dasar untuk Pendidikan. Singaraja: Undiksha.

Apriani, Ni Pt. \& I Dw. Kade Tastra, Pt. Nanci Riastini. 2013. "Pengaruh Model Pembelajaran Arias Berbantuan Media Karikatur terhadap Pemahaman Konsep IPA di SD Gugus X Kecamatan Mengwi”. Jurnal Mimbar PGSD Vol 1 No1.

Bundu, P. 2006. Penilaian Keterampilan Proses dan Sikap Ilmiah dalam Pembelajaran Sains Sekolah Dasar. Jakarta: Departemen Pendidikan Nasional.

Dantes, N. 2017. Desain Eksperimen dan Analisis Data. Depok: PT Raja Grafindo Persada. 
Juniartini, I. A. Komang \& Ni Kt. Suarni, I Gd. Margunayasa.2013. "Pengaruh Model Pembelajaran Arias terhadap Hasil Belajar IPA Kelas IV SD Negeri 3 Banjar Jawa”. Jurnal Mimbar PGSD Vol 1 No 12013 (67) .

Garlina, Pt. Luna \& I Kt. Dibia, Gd. Sedanayasa. 2013." Pengaruh Model Pembelajaran (Arias) Assurance Relevance Interest Assessment Satisfaction Terhadap Keterampilan Berbicara pada Siswa SD di Desa Sari Mekar “.Jurnal Mimbar PGSD Vol 1 No 12013.

Hindayani, Ni Kd Sri. \& Md. Sumantri, Dsk. Putu Parmiti. 2013." Pengaruh Model Pembelajaran Arias (Assurance, Relevance, Interst, Assessment Dan Satisfaction) terhadap Hasil Belajar Matematika di SD. Jurnal Mimbar PGSD Vol 1 No 12013.

Koyan, I. W. 2012. Statistik Pendidikan. Singaraja: Universitas Pendidikan Ganesha Press.

Kushendrati, Ni Luh Febriana \& Nym. Kusmariyatni, I Nym. Murda. 2013. "Pengaruh Model Pembelajaran Arias Berbantuan Mind Mapping Terhadap Minat Dan Motivasi Belajar IPS Siswa Kelas V SD di Gugus Semeru". Jurnal Mimbar PGSD

Lastia, Wyn. Yuni \& Kt. Adnyana Putra, Wyn.Suniasih.2013.. "Pengaruh Model Pembelajaran Arias Terhadap Hasil Belajar IPA Siswa Kelas IV SD Gugus II Ir.Soekarno Denpasar Selatan Tahun Ajaran 2012/2013". Jurnal Mimbar PGSD Vol 1 No 12013.

Pramana, D. G. W. 2015. “Pengaruh Model Pembelajaran ARIAS Terhadap Hasil Belajar IPA Siswa Kelas IV SD". e-Journal Universitas Pendidikan Undiksha PGSD Vol:3 No:1 Tahun 2015. (hlm 1-10).

Pramidana, Kt. Dinda Sukma \& Gd. Sedanayasa, Desak Pt. Parmiti.2013. "Pengaruh Model Pembelajaran Arias Terhadap Hasil Belajar Bahasa Indonesia Siswa Kelas V Sd No. 2 Dan 5 Banyuasri". Jurnal Mimbar PGSD Vol 1 No 12013 (56)

Rahman, M dan Sofan A. 2014. Model Pembelajaran ARIAS Terintegratif. Jakarta:Prestasi Pustaka Publisher.

Samatowa, U. 2011. Pembelajaran IPA di Sekolah Dasar. Jakarta: PT Indeks.

Siahan, P,dkk. 2010. "Penerapan Model ARIAS (Assurance, Relevance, Interest, Assessment dan Satisfaction) dalam Pembelajaran TIK (Teknologi Informasi dan Komunikasi)". Jurnal Pendidikan teknologi Informasi dan Komunikasi (PTIK). Vol.03 No.1 (hlm 23-27). Tersedia padahttp://file.upi.edu?Direktori/JURNAL/PENDIDIKAN_TIK/Jurnal_Pend_TIK_Vol_3_No_1/PENER APAN_MODEL_ARIAS_(ASSURANCE_RELEVANCE_INTEREST_ASSESSMENT_AND_SATISFACTION_)_ DALAM_PEMBELAJARAN_TIK_(TEKNOLOGI_INFORMASI_DAN_KOMUNIKASI).pdf

Sugiyono. 2017. Statistika untuk Penelitian. Bandung: Alfabeta.

Sunarto. 2012. Icebreaker dalam Pembelajaran Aktif. Surakarta: Cakrawala Media.

Susanto, A. 2013. Teori Belajar \& Pembelajaran di Sekolah Dasar. Jakarta: Prenadamedia Group.

Trianto. 2007. Model Pembelajaran Terpadu Dalam Teori dan Praktek. Jakarta: Prestasi Pustaka.

Yasa, I K. A. 2014. "Pengaruh Model Pembelajaran ARIAS Berbantuan Media Gambar terhadap Hasil Belajar IPS Siswa Kelas III SD No. 2 Kuta Kabupaten Badung". e-Journal PGSD Universitas Pendidikan Ganesha Mimbar PGSD Vol. 2 No. 1 Tahun 2014 (hlm 1-10). 